\section{UJMM

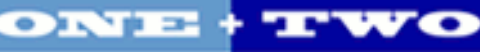

Volume 1 | 2008 Fall

\section{Undergraduate Journal of Mathematical}

Modeling: One + Two

2008

\title{
Criteria Pollutant Concentration
}

Victor Neese

University of South Florida

\author{
Advisors: \\ Leslaw Skrzypek, Mathematics and Statistics \\ Jeff Cunningham, Civil \& Environmental Engineering \\ Problem Suggested By: Jeff Cunningham
}

Follow this and additional works at: https://digitalcommons.usf.edu/ujmm

Part of the Mathematics Commons

UJMM is an open access journal, free to authors and readers, and relies on your support:

Donate Now

\section{Recommended Citation}

Neese, Victor (2008) "Criteria Pollutant Concentration," Undergraduate Journal of Mathematical Modeling: One + Two: Vol. 1: Iss. 1, Article 2.

DOI: http://dx.doi.org/10.5038/2326-3652.1.1.2

Available at: https://digitalcommons.usf.edu/ujmm/vol1/iss1/2 


\title{
Criteria Pollutant Concentration
}

\begin{abstract}
With the assistance of Assistant Professor Jeff Cunningham (Civil \& Environmental Engineering Department, USF) a study was carried out pertaining to the amount of $\mathrm{CO}$ and NOx pollutants emitted from a highway having two lanes in each direction. The receptor of the pollutants is a hypothetical housing development located near the highway. The concentrations were found by utilizing information regarding meteorological conditions, estimated emissions rates, and distances from the highway less than or equaling $2 \mathrm{~km}$.
\end{abstract}

Keywords

Stability, Emissions Rates, Meteorological Conditions

Creative Commons License

(c) (i) (3)

This work is licensed under a Creative Commons Attribution-Noncommercial-Share Alike 4.0 License. 


\section{Motivation}

When deciding on the location of a new housing development, it is crucial to consider the air quality of the area in which the development is to be constructed. If considering construction near a highway, pollution emitted from automobiles is a major factor affecting the quality of air around the chosen site. In order to make the best possible decision on a location with the least pollution, it is necessary to study the concentration of pollution at various distances from the highway.

The two pollutants considered in this study are Carbon Monoxide (CO), and Nitrous Oxides (NOx). These pollutants are considered "criteria air pollutants." Criteria air pollutants are a group of the six most common pollutants that endanger public health and the environment. Because of their threat to society, these pollutants have been regulated by the Clean Air Act of congress, which defines allowable concentrations in the air. The levels of these two pollutants, if high enough, can cause major health problems and even death.

The concentrations of these two hazardous pollutants are measured at various distances from the highway. The expanse of these distances will range from $0.2 \mathrm{~km}$ to $2.0 \mathrm{~km}$. As the study is carried out, a graphic representation of the concentrations of $\mathrm{CO}$ and NOx will be provided.

\section{Mathematical Description and Solution Approach}

Our first step involved researching the emissions rates of the common vehicles on the road today. Using the information found for one vehicle, an estimate was made of the emissions from all cars traveling down a kilometer stretch of highway in one day. First, the number of vehicles per minute on a $1 \mathrm{~km}$ stretch of highway was estimated. This number was used to find vehicles per hour and vehicles per day.

This estimate of vehicles for a period of 24 hours was only an estimate for one lane of the highway. The highway being considered is a 4-lane highway. The estimate for all four lanes would be four times the previous estimate. After the amount of vehicles per day per $\mathrm{km}$ was estimated, we figured the rate of emissions by these cars. Using the estimated amount of vehicles per day per km of highway, estimates of CO and NOx emissions were made by finding the product of this estimate and the emissions rate per kilometer of one vehicle. The calculations and results of these findings can be found in Figure 1 of the appendix.

The next step was to determine common meteorological conditions for West Central Florida (between Tampa and Gainesville) and to determine a stability class for this region. This 
information will be useful for determining the plume dispersion of the pollution cloud emitted from the pollution source. A stability class will be necessary later on in the paper.

The term 'stability' refers to the tendency of the atmosphere to resist or enhance vertical motion. A stability class is a factor required in order to understand and estimate the dispersion of the pollutant cloud plume in relation to distance. In order to decide on a particular stability class for the region of West Central Florida, it was necessary to research the usual meteorological conditions that take place throughout a given month. The month considered in this paper is November.

Using an online Weather Almanac of meteorological conditions in Tampa from the year 2000 to the year 2007 for the entire month of November, average wind speeds, cloud cover and temperatures were compiled to make a logical decision about this region's stability class. The information can be viewed in Figure 2 of the appendix.

Given the common meteorological conditions of West Central Florida, the stability class " $C$ " was chosen. Using this stability class, the calculations involving plume dispersion are now accessible. These calculations involve two equations developed by D.O. Martin, which depict the plume dispersion in meters with respect to $y$ and $z$ coordinates, $y$ being the horizontal and $z$ being the vertical:

$$
\sigma_{y}=a x^{0.894} \text { and } \sigma_{z}=c x^{d}+f
$$

The variable $x$ measures the distance in meters from the highway. The constants $a, c, d$, and $f$ are defined in the textbook Principles of Environmental Engineering and Science, by Mackenzie L. Davis and Susan J. Masten in tables 11-17 and 11-18. Other information pertinent to the calculations of plume dispersion is included from the text in Figure 3 of the appendix.

By varying the distance $(x)$ in kilometers, the dispersion of the pollutant cloud plume can be figured. The distances considered for this paper are for values of $x$ ranging from $0.2 \mathrm{~km}$ from the highway to $2.0 \mathrm{~km}$ from the highway. The results of the plume dispersion calculations can be viewed in Figure 4 of the appendix.

With the new findings of plume dispersion based on varied distances, the next phase begins. The concentrations of $\mathrm{CO}$ and NOx can now be evaluated over the same distances used above $(0.2 \mathrm{~km}$ to $2.0 \mathrm{~km})$ by means of a complex formula:

$$
C(x, y, z)=\frac{E}{2 \pi \omega \sigma_{y} \sigma_{z}} e^{\frac{-y^{2}}{2 \sigma_{y}{ }^{2}}} \cdot\left\{e^{\frac{-(2-H)^{2}}{2 \sigma_{z}{ }^{2}}}+e^{\frac{-(2+H)^{2}}{2 \sigma_{z}^{2}}}\right\}
$$


In this equation, $E$ represents the emission rate of pollutant, $\omega$ is wind speed, and $H$ is the receptor height.

The receptor height for this paper was taken as the average height of a person, which is about $1.5 \mathrm{~m}$ from the ground. The wind speed was taken as $6.375 \mathrm{mph}$, which is the average wind speed for this region of Florida as found from the meteorological data in figure 2 . For emissions rates, there are separate figures, one for $\mathrm{CO}$ emissions and one for NOx emissions. These were found using the estimates from figure 1 for emissions per day. The calculations for the emissions of $\mathrm{CO}$ and NOx can be found in Figure 5 of the appendix. Now, the factors needed to calculate the concentrations of a particular pollutant at various distances are all known. The above equation is used for finding the concentration at a receptor from only one section of the highway. We need the concentration from the entire highway. In order for these calculations it is necessary to integrate $C(x, y, z)$ from negative infinity to positive infinity:

$$
C(x, y, z)=\frac{E}{2 \pi \omega \sigma_{y} \sigma_{z}}\left\{e^{\frac{-(2-H)^{2}}{2 \sigma_{z}^{2}}}+e^{\frac{-(2+H)^{2}}{2 \sigma_{z}^{2}}}\right\} \int_{-\infty}^{+\infty} e^{\frac{-y^{2}}{2 \sigma_{y}^{2}}} d y
$$

The function to be integrated is somewhat complex, so we will refer to an integral table. A simplification of this integral can be found in Figure 6 of the appendix. Next, we find each concentration at each distance $(0.2 \mathrm{~km}$ to $2.0 \mathrm{~km}$ from the highway) using the new, simplified form of equation above. After finding each concentration at each distance and depicting the information in a graph, an optimal distance is chosen for the construction of new housing development near the highway. The calculations and graphs of the concentrations can be viewed in Figures 7 and 8 of the appendix, respectively.

\section{Discussion}

The concentrations of Carbon Monoxide and Nitrogen Oxide emitted from all the vehicles on the highway diminish in a casual manner until they are almost negligible. The healthiest choice for a housing development is, of course, more than $2 \mathrm{~km}$ from the highway, but ideal locations are not always an option. As you approach 0.2 kilometers from the highway however, the levels of $\mathrm{CO}$ and NOx are much greater than around 0.6 kilometers. From 0.6 kilometers and further away from the highway, the levels are somewhat constant. If a housing development were to be built near the highway, either 0.6 kilometers or further away would be a good distance for the development.

The objective of this paper was to find the various concentrations at varied distances from the highway at a receptor 1.5 meters off the ground. Through calculus, research and educated 
estimation, this objective was met. All data collected and all calculations made along with a graph of the concentrations at each distance are provided in the appendix.

Most findings were consistent with my expectations. Since the outside environment quickly disperses most fumes as well as smoke from fires, I figured that pollutants emitted from cars along a highway would act in a similar manner. I was not sure just how quickly these pollutants would be dissipated and the results showed me just how quickly and effectively the environment acts upon gasses released into open air conditions.

\section{Conclusions and Recommendations}

The purpose of this paper was to determine the concentrations of Carbon Monoxide and Nitrogen Oxides emitted from vehicles travelling down a hypothetical four-lane highway with two lanes in each direction. The receptor of the emitted pollutants was a hypothetical housing development located near the highway. As a mark for the receptor height, the size of an average person was chosen as $1.5 \mathrm{~m}$.

As determined by the results of the data, the most ideal location for a housing development would be far from a highway. Pollution, however, is inescapable and ideal conditions are not always available in the world today. Working with the findings, a housing development 0.6 kilometers from the highway or further would be a good choice for the health and the wellbeing of those who will inhabit the future development.

For a more accurate measure of the concentrations of such a situation, an actual receptor could be used in order to find the exact amounts of pollutants for a particular area. Also, more research into how many cars are actually travelling down a typical four lane highway on any given day would make a more accurate estimation. The types of vehicles on the highway today was considered to a great degree, however, if one were to compile a report of vehicles on the highway throughout the year, noting vehicle size and type, the estimates would be even more accurate. 


\section{References}

Davis, Mackenzie, and Susan J. Masten. Principles of Environmental Engineering and Science. '1st ed. New York, NY: Mcgraw-Hill, 2004.

Environmental Protection Agency, "Emissions Facts." EPA420-F-00-013 April 2000 <http://www.epa.gov/otaq/consumer/f00013.htm>.

Weather Underground, "History for Tampa, FL." <EPA, "Emissions Facts."< http://www.wunderground.com/history/airport/KTPA/2007/11/1/DailyHistory.html>

Davis, Tony. "Cars and Pollution." June 19, 2007 <http://www.adeq.state.ar.us/AIR/ozone/cars.htm>.

Reinhold, Robert. "Ford Unveils Cleanest-Running Cars for California." April 15, 1992 <http://query.nytimes.com/gst/fullpage.html?res=9E0CE2DB1031F936A25757C0A964958260\& sec $=\&$ spon $=\&$ pagewanted $=$ all $>$.

Harding, Beau. "Car Pollution." <http://beauharding.com/>.

Fleming, James and Knorr Bethany of Colby College "Clean Air Act." 1999 <http://www.ametsoc.org/Sloan/cleanair/index.html>.

Scorecard, "Criteria Air Pollution." $2005<$ http://www.scorecard.org/envreleases/def/cap_gen.html>.

Environmental Protection Agency, "Clean Air Act." Nov 212008 <http://www.epa.gov/air/caa/>. 


\section{Appendix}

Figure 1: Emissions Rates Estimates and Calculations

Emissions Rate of $\mathrm{CO}$ and NOx from One Vehicle: $5.7 \mathrm{~g} \mathrm{CO} / \mathrm{km}$ and $1.28 \mathrm{~g} \mathrm{NOx} / \mathrm{km}$

(Rates estimated utilizing information from http://www.beauharding.com )

Estimates of Vehicles on One Lane Each Day: 20 vehicles per minute

$$
\begin{aligned}
& 1200 \text { vehicles per hour } \\
& 28800 \text { vehicles per day }
\end{aligned}
$$

Calculations of CO and NOx from a Four Lane Highway (Two Lanes Each Way) Each Day:

28800 cars per day $\times 5.7 \mathrm{~g} \mathrm{CO} / \mathrm{km} \times 4$ lanes of traffic $=656640 \mathrm{~g} \mathrm{CO} / \mathrm{km} / \mathrm{day}$

28800 cars per day $\times 1.28 \mathrm{~g} \mathrm{NOx} / \mathrm{km} \times 4$ lanes of traffic $=147456 \mathrm{~g} \mathrm{NO} / \mathrm{km} /$ day

\begin{tabular}{|c|c|c|c|c|c|c|c|c|}
\hline Year & 2000 & 2001 & 2002 & 2003 & 2004 & 2005 & 2006 & 2007 \\
\hline $\begin{array}{l}\text { Average } \\
\text { Temperature }\end{array}$ & $66^{\circ} \mathrm{F}$ & $71^{\circ} \mathrm{F}$ & $65^{\circ} \mathrm{F}$ & $71^{\circ} \mathrm{F}$ & $70^{\circ} \mathrm{F}$ & $71^{\circ} \mathrm{F}$ & $68^{\circ} \mathrm{F}$ & $69^{\circ} \mathrm{F}$ \\
\hline $\begin{array}{l}\text { Average } \\
\text { Wind Speed }\end{array}$ & $5 \mathrm{mph}$ & $5 \mathrm{mph}$ & $6 \mathrm{mph}$ & $7 \mathrm{mph}$ & $6 \mathrm{mph}$ & $7 \mathrm{mph}$ & $8 \mathrm{mph}$ & $7 \mathrm{mph}$ \\
\hline $\begin{array}{l}\text { Usual } \\
\text { Amount of } \\
\text { Cloud Cover }\end{array}$ & $\begin{array}{l}\text { Mostly } \\
\text { Cloudy }\end{array}$ & $\begin{array}{l}\text { Partial } \\
\text { Cloud } \\
\text { Cover }\end{array}$ & Clear & Clear & $\begin{array}{l}\text { Partial } \\
\text { Cloud } \\
\text { Cover }\end{array}$ & $\begin{array}{l}\text { Partial } \\
\text { Cloud } \\
\text { Cover }\end{array}$ & $\begin{array}{l}\text { Mostly } \\
\text { Cloudy }\end{array}$ & Clear \\
\hline $\begin{array}{c}\text { Concl } \\
- \\
- \\
- \\
-\end{array}$ & $\begin{array}{l}\text { usions: } \\
\text { Usually } \\
\text { Temper } \\
\text { Wind Sp } \\
\text { Stability }\end{array}$ & $\begin{array}{l}\text { artial Clo } \\
\text { ture Aver } \\
\text { eed Avera } \\
\text { Class cho }\end{array}$ & $\begin{array}{l}\text { Id Cover } \\
\text { age is } 69^{\circ} \\
\text { ge is } 6.37 \\
\text { en "C" }\end{array}$ & $\begin{array}{l}\text { o Clear C } \\
\text { F } \mathrm{mph}\end{array}$ & nditions & & & \\
\hline
\end{tabular}

Figure 2: Meteorological Conditions for Tampa Florida from year 2000 to 2007 
Figure 3: Information from Text - Principles of Environmental Engineering and Science

\section{Pertinent Information from Table 11-7 and Table 11-8:}

Values of a, c, d, and f for Calculating $\sigma_{y}$ and $\sigma_{z}$

For values of $x$ less than $1 \mathrm{~km}$ and stability class of C:

$$
a=104, c=61, d=0.911, f=0
$$

For values of $\mathrm{x}$ greater than or equal to $1 \mathrm{~km}$ and stability class $\mathrm{C}$ :

$$
a=104, c=61, d=0.911, f=0
$$

Figure 4: Calculations and Results of Plume Dispersion for $S_{y}$ and $S_{z}$

\begin{tabular}{||l|l|l||}
\hline Distance $(\mathrm{x})$ in $\mathrm{km}$ & \multicolumn{1}{|c|}{$\sigma_{y}=a x^{0.894}$} & \multicolumn{1}{c|}{$\sigma_{z}=c x^{d}+f$} \\
\hline $\mathrm{x}=.2$ & $\sigma_{y}=104(.2)^{0.894}=24.67 \mathrm{~m}$ & $\sigma_{z}=61(.2)^{0.911}+0=14.08 \mathrm{~m}$ \\
\hline $\mathrm{x}=.4$ & $\sigma_{y}=104(.4)^{0.894}=45.84 \mathrm{~m}$ & $\sigma_{z}=61(.4)^{0.911}+0=26.47 \mathrm{~m}$ \\
\hline $\mathrm{x}=.6$ & $\sigma_{y}=104(.6)^{0.894}=65.87 \mathrm{~m}$ & $\sigma_{z}=61(.6)^{0.911}+0=38.30 \mathrm{~m}$ \\
\hline $\mathrm{x}=.8$ & $\sigma_{y}=104(.8)^{0.894}=85.19 \mathrm{~m}$ & $\sigma_{z}=61(.8)^{0.911}+0=49.78 \mathrm{~m}$ \\
\hline $\mathrm{x}=1.0$ & $\sigma_{y}=104(1.0)^{0.894}=104.00 \mathrm{~m}$ & $\sigma_{z}=61(1.0)^{0.911}+0=61.00 \mathrm{~m}$ \\
\hline $\mathrm{x}=1.2$ & $\sigma_{y}=104(1.2)^{0.894}=122.41 \mathrm{~m}$ & $\sigma_{z}=61(1.2)^{0.911}+0=72.02 \mathrm{~m}$ \\
\hline $\mathrm{x}=1.4$ & $\sigma_{y}=104(1.4)^{0.894}=140.49 \mathrm{~m}$ & $\sigma_{z}=61(1.4)^{0.911}+0=82.88 \mathrm{~m}$ \\
\hline $\mathrm{x}=1.6$ & $\sigma_{y}=104(1.6)^{0.894}=158.31 \mathrm{~m}$ & $\sigma_{z}=61(1.6)^{0.911}+0=93.60 \mathrm{~m}$ \\
\hline $\mathrm{x}=1.8$ & $\sigma_{y}=104(1.8)^{0.894}=175.89 \mathrm{~m}$ & $\sigma_{z}=61(1.8)^{0.911}+0=102.49 \mathrm{~m}$ \\
\hline $\mathrm{x}=2.0$ & $\sigma_{y}=104(2.0)^{0.894}=193.27 \mathrm{~m}$ & $\sigma_{z}=61(2.0)^{0.911}+0=114.70 \mathrm{~m}$ \\
\hline
\end{tabular}

Figure 5: Emissions Rate (E) for grams/second Calculations

$$
\begin{aligned}
& \text { Emissions in grams/second of CO: } \frac{656640 \mathrm{~g} \mathrm{CO}}{1 \text { day }} \times \frac{1 \text { day }}{86400 \text { seconds }}=7.6 \mathrm{grams} / \mathrm{second} \\
& \text { Emissions in grams/second of NOx: } \frac{147456 \mathrm{~g} \mathrm{NOx}}{1 \text { day }} \times \frac{1 \text { day }}{86400 \text { second }}=1.7 \mathrm{grams} / \mathrm{second}
\end{aligned}
$$


Figure 6: Simplification of Original Concentration Equation

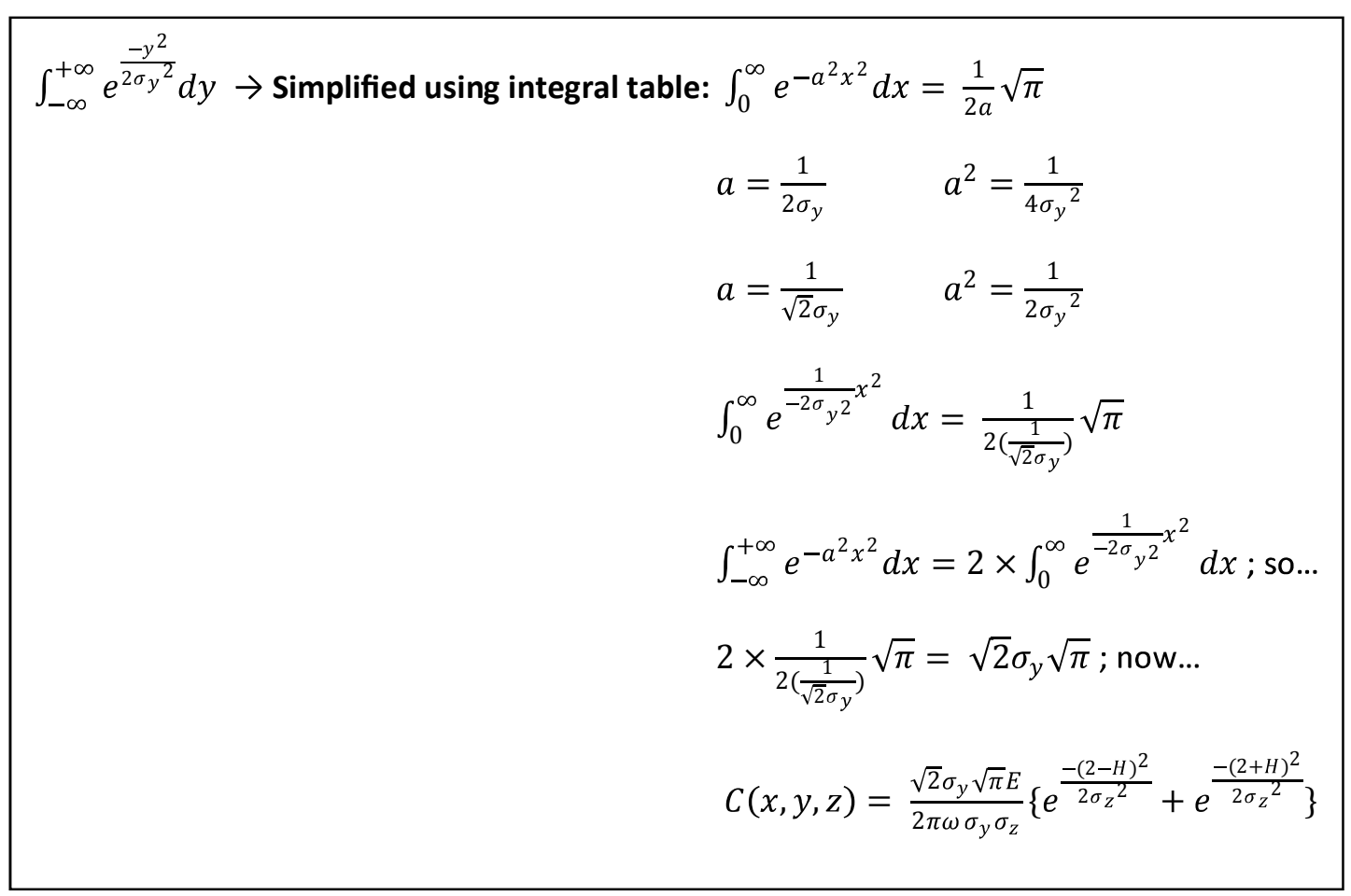

Figure 7: Calculations of Concentrations Using Simplified Formula

\begin{tabular}{|c|c|c||}
\hline \multicolumn{3}{|c||}{ Base Formula: $C(x, y, z)=\frac{\sqrt{2} \sigma_{y} \sqrt{\pi} E}{2 \pi \omega \sigma_{y} \sigma_{z}}\left\{e^{\frac{-(2-H)^{2}}{2 \sigma_{z}^{2}}}+e^{\frac{-(2+H)^{2}}{2 \sigma_{z}^{2}}}\right\}$} \\
\hline Distance from Highway & Concentration of CO & Concentration of NOx \\
\hline $0.2 \mathrm{~km}$ & $6.72389146 \mathrm{EE}-2$ & $1.50402835 \mathrm{EE}-2$ \\
\hline $0.4 \mathrm{~km}$ & $3.58871292 \mathrm{EE}-2$ & $8.0273842 \mathrm{EE}-3$ \\
\hline $0.6 \mathrm{~km}$ & $2.48197383 \mathrm{EE}-2$ & $5.5517745 \mathrm{EE}-3$ \\
\hline $0.8 \mathrm{~km}$ & $1.91009203 \mathrm{EE}-2$ & $4.2725743 \mathrm{EE}-3$ \\
\hline $1.0 \mathrm{~km}$ & $1.55895727 \mathrm{EE}-2$ & $3.4871412 \mathrm{EE}-3$ \\
\hline $1.2 \mathrm{~km}$ & $1.3205105 \mathrm{EE}-2$ & $2.9537735 \mathrm{EE}-3$ \\
\hline $1.4 \mathrm{~km}$ & $1.114753106 \mathrm{EE}-2$ & $2.5668459 \mathrm{EE}-3$ \\
\hline $1.6 \mathrm{~km}$ & $1.01612924 \mathrm{EE}-2$ & $2.2729322 \mathrm{EE}-3$ \\
\hline $1.8 \mathrm{~km}$ & $9.2801119 \mathrm{EE}-3$ & $2.0758145 \mathrm{EE}-3$ \\
\hline $2.0 \mathrm{~km}$ & $8.2923781 \mathrm{EE}-3$ & $1.8548741 \mathrm{EE}-4$ \\
\hline
\end{tabular}


Figure 8: Graph of Concentrations of $\mathrm{CO}$ and NOx

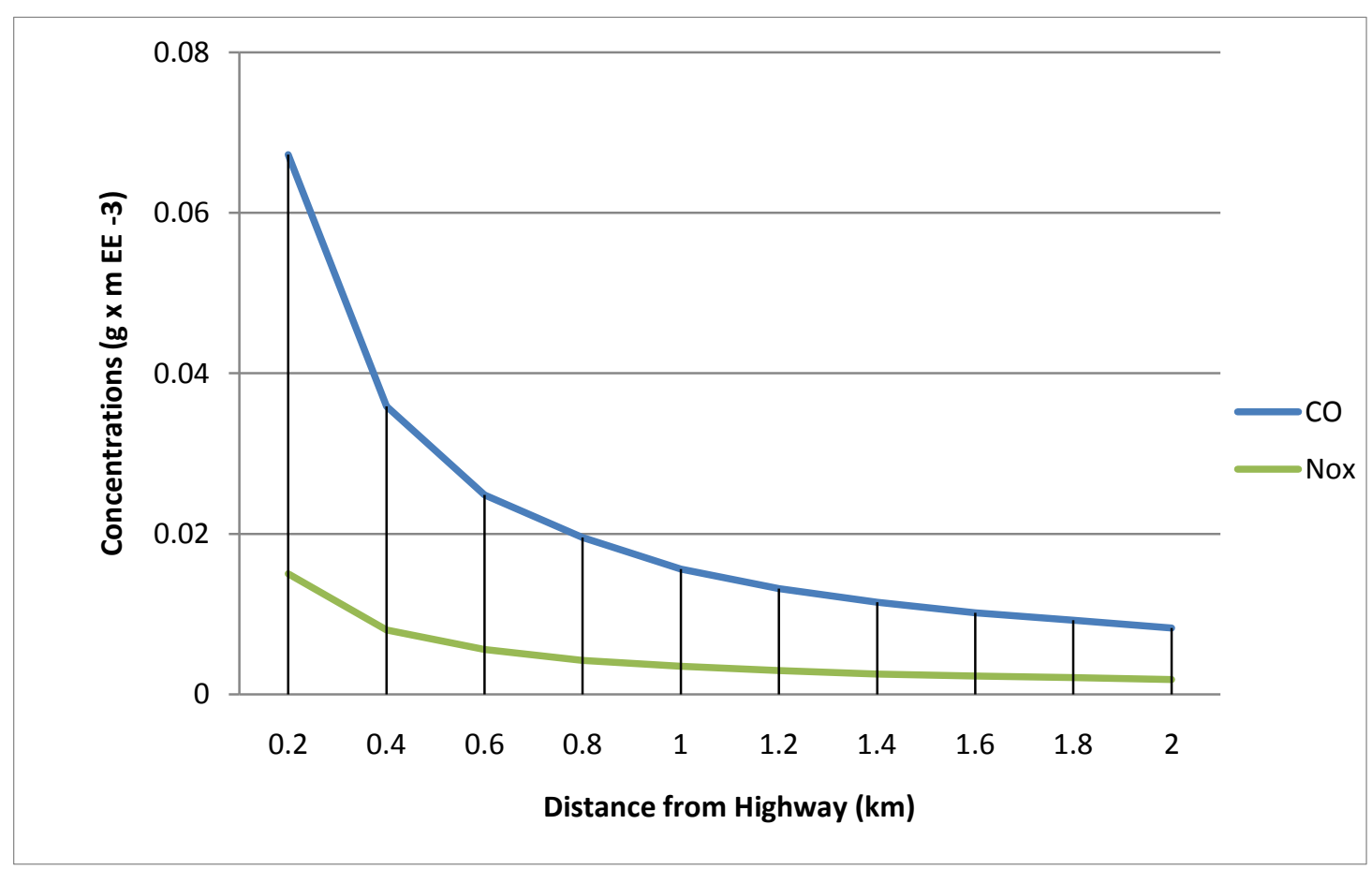

Figure 9: If only, If only..

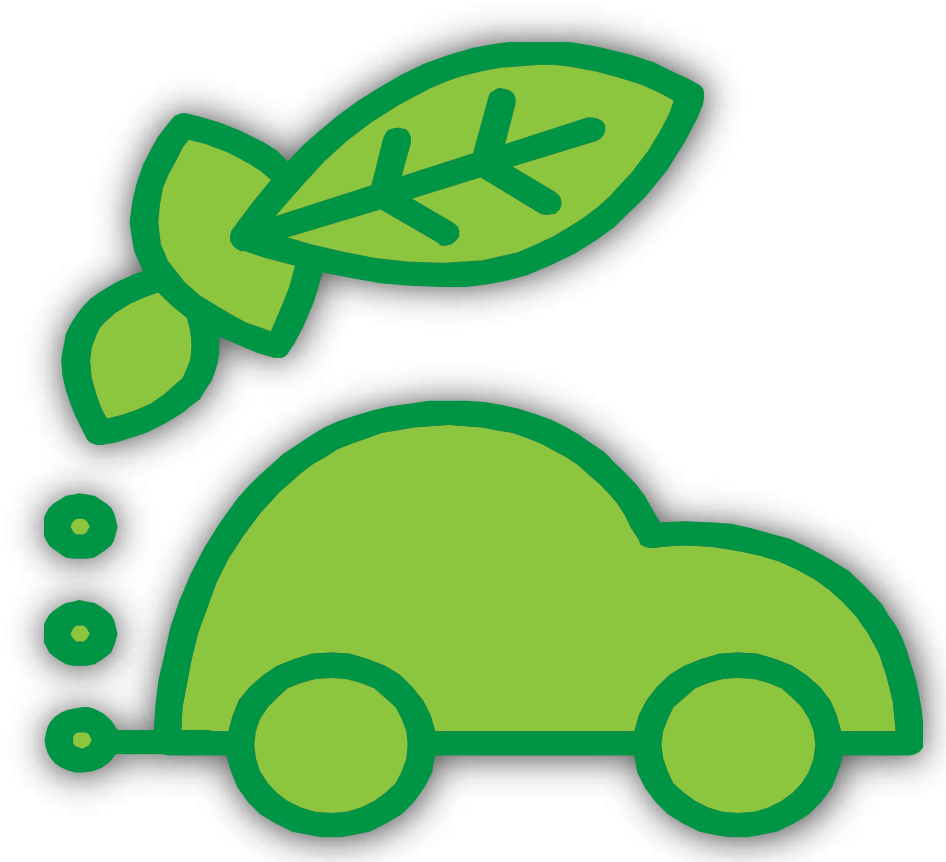

